\title{
Arteriovenous fistula for dialysis - what do we know today?
}

\author{
Andrzej Berszakiewicz', 2, Agata Stanek', Natalia Strzelczyk', \\ Kamila Gebala-Prajsnar', Aleksander Sieron' \\ 'School of Medicine with the Division of Dentistry in Zabrze, Department of Internal Medicine, Angiology and Physical Medicine, \\ Medical University of Silesia, Bytom, Poland \\ ${ }^{2}$ Fresenius Dialysis Centre, No. 38 in Oswiecim, Fresenius Nephrocare Polska
}

\begin{abstract}
Since the number of patients awaiting dialysis and survival time for kidney dialysis patients are on the increase, the issue of pre-emptive vascular access creation, care and use for hemodialysis is gaining importance. This paper summarizes the principles, policies and procedures aimed to achieve the longest survival time and the best possible quality of life in patients on renal replacement therapy.
\end{abstract}

Key words: dialysis, arteriovenous fistula, chronic kidney disease

Acta Angiol 2017; 23, 3: 144-150

\section{Introduction}

Civilization diseases including arterial hypertension, atherosclerosis and type 2 diabetes mellitus are the most frequent causes of chronic kidney disease (CKD). Epidemiological spread of civilization diseases is likely to increase CKD prevalence and severity. At present, the mean prevalence of CKD in highly developed countries is $10-15 \%$ (other sources quote I0-I I.5\%). The overall prevalence of CKD increases with age which is in itself a challenge in the context of the world's population growth and aging. The prevalence of CKD in the Polish population over the age of 65 is $29.4 \%$ [I-3].

The number of dialysis patients increases each year. Nearly I.9 million people worldwide underwent dialysis in the year 2010 [3]. Also, more patients require long-term renal replacement therapy. The majority of patients are qualified for dialysis when diagnosed with estimated glomerular filtration rate (eGFR) below
$15 \mathrm{~mL} / \mathrm{min} / 1.73 \mathrm{~m}^{2}$ and uremic symptoms or eGFR levels of $8-10 \mathrm{~mL} / \mathrm{min} / 1.73 \mathrm{~m}^{2}$ and no uremia. Diabetic patients start dialysis therapy when the eGFR falls to less than $20 \mathrm{~mL} / \mathrm{min} / 1.73 \mathrm{~m}^{2}[4,5]$.

A mainstay to perform an efficient hemodialysis is an appropriate and well-functioning vascular access that allows collection of large blood volumes. Such access must withstand regularly repeated large-volume blood collections while the risk for infectious, thrombotic and hemorrhagic complications as well as morbidity and mortality are limited to a minimum. An autologous arteriovenous fistula (AVF) seems to satisfy these requirements. Despite rapid development of extracorporeal dialysis technology, AVF remains the gold standard for maintaining access to the circulatory system [4]. Considering limited kidney graft survival, creation of AV fistulas is also considered in renal transplanted patients and those awaiting kidney transplantation [6]. If a native fistula cannot be created, another option is an artificial arteriovenous graft (AVG). 


\section{Timing of AVF creation and preoperative patient assessment}

Stages 3 and 4 CKD are the time to educate the patient. It is recommended that patients should avoid too frequent cannulation of the main superficial veins of the forearm associated with intravenous infusions, drug administration or blood sampling [5, 7]. The patient should be advised to take up dynamic physical exercises to strengthen vascular walls, increase blood flow (BF) and reduce edema [5].

Pre-emptive AVF creation significantly reduces the mortality and morbidity within the population of patients on renal replacement therapy. The conditions to create a well-functioning fistula are optimal timing of vascular access surgery, selection of the best blood vessels and appropriate use and care of the $\operatorname{AVF}[3,8]$. According to European recommendations, AVF should be created at stage 4 CKD, i.e. eGFR level below $30 \mathrm{~mL} / \mathrm{min} / 1.73 \mathrm{~m}^{2}$ while patients with diabetes mellitus, severe peripheral vascular disease or rapid CKD progression should have their AVF created even before that stage [9]. AVF creation should be preceded by meticulous history taking and through physical examination. The patient's medical history should include information regarding past injuries of the upper extremities and the shoulder girdle; the patient should be asked about surgical interventions (mastectomy, pacemaker implantation), phlebitis, phlebothrombosis, large vessel cannulation (nearly $40 \%$ of patients develop major central venous stenosis after subclavian vein cannulation) $[7,10,1 \mathrm{I}]$. Cardiac status should be assessed as the arteriovenous fistula is believed to be an independent risk factor for cardiovascular disease due to promotion of hyperkinetic circulation [12]. Older age, diabetes mellitus, extensive atherosclerosis and secondary hyperparathyroidism, frequently seen in patients with CKD, are associated with vessel pathologies including Mönckeberg disease more commonly seen in people with diabetes than in general population, and vessel calcifications typical of secondary hyperparathyroidism. Questions should be asked about clotting disorders, use of anticoagulant or antithrombotic therapy. A detailed physical examination is mandatory prior to AVF creation. Scars, local inflammatory conditions, limb edema or asymmetry should all be identified. Blood supply to the upper extremity should be determined based on arterial blood pressure measurement and pulse symmetry. The absence of clearly palpable pulse in the radial artery indicates the vessel cannot be converted to a vascular access with blood flow exceeding $1000 \mathrm{~mL} / \mathrm{min}$ [II, I3]. Allen's test should be performed to confirm normal dual blood supply to the hand and pressure gradients of upper extremities should be deter- mined. Systolic pressure gradient should be lower than $15 \mathrm{~mm} \mathrm{Hg}$ between the brachial arteries for an arm fistula and lower than $15 \mathrm{~mm} \mathrm{Hg}$ between ipsilateral brachial and radial arteries for a forearm fistula [ 10$]$. It is also essential to examine the superficial venous system, in particular vessel availability and course, and check for collateral circulation, the presence of which is considered a sign of venous drainage disturbances. Addressing the potential need for subsequent vessel superficialization, subcutaneous tissue thickness is also assessed [4, 14]. Noninvasive ultrasound of veins and arteries is of much assistance; temperature in the examination room should not fall below $20-22^{\circ} \mathrm{C}$. Hot compresses on the limb will facilitate vessel dilation and measurement of its maximum diameter $[10,15]$. Ultrasound mapping allows the assessment of all vessels with respect to their diameters, course, patency and stenosis. Caliber and quality of the vessels are of key importance for maintenance of function. The radial artery and brachial artery segment right above the cubital fossa are typically assessed and, in the venous system, the cephalic and basilica veins along their entire length $[10,13]$. Arterial and vein diameters (AD, VD, respectively) are predictive of AVF outcomes. It has been reported that AVF failed if radial artery diameter was smaller than $2 \mathrm{~mm}$ or, according to other studies, smaller than $1.6 \mathrm{~mm}[4$, $\mathrm{II}, 16]$. It is therefore recommended to use arteries $\geq 2 \mathrm{~mm}$ in diameter. For veins, diameters of $\geq 2.5-3 \mathrm{~mm}$ guarantee adequate fistula maturation. However, success of an AVF depends not only on vein diameter but also its preoperative distensibility $[10,16]$. It is believed there is no AVF maturation without remodeling of both inflow and outflow limbs in response to hemodynamic changes following AVF formation [13, I7]. VD $<2 \mathrm{~mm}$ positively correlates with high incidence of early thrombosis $[10,16]$. The problem of small vessel size and distensibility is more common in women $[15,18]$. Ultrasound examination also allows assessment of vessel course and anatomic variants. For example high brachial artery bifurcation (above the elbow, typically in the axillary region) may complicate AVF maturation and, in the case of AVG, increase the risk of thrombosis. Ultrasound also allows flow spectrum estimation. Loss of respiratory phasicity in the axillary vein is suggestive of central venous stenosis [II]. Radiological investigations are recommended in selected patients with diabetes and secondary hyperparathyroidism to check for vascular calcifications [4].

Invasive examinations performed prior to AVF creation include arteriography and venography. On assessment of the arterial system, contrast medium is injected at the level of the aortic arch or, selectively, to the subclavian artery at the investigated side. In venography, a contrast agent is administered to a peripheral 
vein, most frequently on the dorsum of the hand. Before dialysis, carbon dioxide and gandolinium are the contrast media to produce a venogram or arteriogram, respectively [10]. Considering their nephrotoxicity, iodinated contrast materials should not be used prior to renal replacement therapy [I0].

\section{Types of AV fistula for dialysis; site and method of AVF creation}

AVF can be created in the majority of candidates for dialysis. Eighty-three percent of patients in Italy and $93 \%$ of patients in Japan undergo dialysis with a fistula. Elderly age should not preclude AV fistula creation. However, in patients over the age of 80 , individual patient's preferences and concomitant diseases should be considered. Nevertheless, $93.5 \%$ of the population over the age of 75 are suitable for AV fistula creation $[19,20]$.

Native accesses are characterized by higher survival and lower complication and thrombosis rates; stenosis and ischemic steal syndrome are quite rare [4]. The very first was a side-to-side Cimino-Brescia fistula connecting the radial artery with the cephalic vein at the wrist; it is still considered the native vascular access of choice in the forearm area [4, 2I]. Other options are end-to-side (vein to artery) and end-to-end (also vein to artery) anastomoses. An end-to-side anastomosis is the most recommended while end-to-end connection is only used for reconstruction or for primary but emergency access [18]. End-to-end anastomosis yields higher rates of hand ischemia, especially in diabetic and elderly patients. It is currently advised that the method of AVF creation should be selected based on individual patient's vessel anatomy [13]. Generally - on the non-dominant hand and the most distally, i.e. starting with the anatomical snuffbox as this offers the longest vein segment for hemodialysis punctures $[4,9,19]$. This is of much importance for inserting the second dialysis needle outside the so-called recirculation zone, that is at a distance of $3-5 \mathrm{~cm}$ from the first needle. A shorter distance between the dialysis needles is associated with a risk of purified blood returning to the dialyzer system, which significantly reduces the efficiency of hemodialysis treatment [22]. Distal AVF provides a chance of subsequent creation of secondary forearm fistulas.

In the case of end-to-side fistulas, the preferred anastomotic angle is between 42 and $45^{\circ}$ as this minimizes neointimal formation. Other researchers favor $30^{\circ}$, still others opt for anastomotic angles of up to $49^{\circ}$. No strict recommendations have been published so far; the above recommendations are based on experts' opinion. The length of the anastomosis depends on the surgeon and is typically $6-10 \mathrm{~mm}$. Anastomoses longer than $10 \mathrm{~mm}$ do not yield substantial benefits $[13,17]$. It should be remembered that AVF site determines its survival. Cumulative AVF patency rates at 2 and 3 years of renal replacement therapy were 70 and $58 \%$ respectively [5]. Native forearm AVFs had one and three years patency rates of $48-69 \%$ and $36-48 \%$; the respective values for elbow area AVFs were higher and amounted to $67-84 \%$ and $50-78 \%$. No consistent recommendations are available regarding first AV fistula site in patients over the age of $\mathbf{8 0}$. Some authors opt for elbow area AVF, especially in women with diabetes mellitus; others believe that the function and durability of forearm AVFs are comparable [8, 2I].

The first to be developed in the forearm area is the radial artery-cephalic vein fistula, with simultaneous ligation of peripheral branches [9]. Then follow: an ulnar-basilic, basilic-vein-transposition and radial artery-perforating vein (a variant of the Gracz fistula) anastomoses [4]. On the upper arm, a fistula can be created between the brachial artery and perforating vein (Gracz fistula) or brachial artery and cephalic vein. Another option is to dissect and superficialize the basilic vein and anastomose it to the brachial artery. If no veins of adequate diameter are available, the radial artery can be anastomosed with the nearest vein awaiting vessel dilation suitable for dialysis [9].

Artificial materials are used when native vessels are not available, i.e. patients are poor candidates for an AVF. Arteriovenous grafts are placed at different levels of upper extremities and anterior thorax [9]. When the central venous drainage of left and right upper extremities is compromised, unilateral central venous drainage is compromised and the other extremity had previously been amputated or an infection/stealing syndrome were diagnosed in the upper extremities, AVG can also be placed in the lower extremities [23]. The ends of polytetrafluoroethylene (PTFE) and polyurethane (PVAG) vascular access grafts [24] are sutured to the side of an artery or vein [4]. A two-year follow-up revealed comparable patency and complication rates for PTFE and PVAG. At I year, the primary patency rate for upper arm AVGs was between 40-71\% (other authors reported $52-64 \%$ ) decreasing to $4 I-49 \%$ at 2 years [2I, 24]. The primary patency of upper arm AVGs is believed to depend on the access inflow. Radial artery ensures higher primary AVG patency rates compared to the brachial artery (53.8\% vs. $24.4 \%$ ) [25]. The primary patency rate for AVGs placed in the lower extremities was lower compared to upper arm AVGs and amounted to $34-66 \%$ at I year and $40 \%$ after 2 years [23]. It has been reported that PVAG grafts were associated with fewer hemorrhagic complications, lower risk of infection and anemia exacerbation [24]. However, compared to native access for dialysis, AVGs yield higher infection 
and thrombosis rates, lower primary patency, higher rates of the stealing syndrome and episodes of critical limb ischemia including those leading to amputation $[15,23,24]$. Still, the use of an AVG is associated with lower risk of sepsis, hospitalization, and mortality when compared with a central venous catheter [26].

AVF creation and maintenance of patency pose considerable problems in $20 \%$ of dialysis patients. Vascular access difficulties are mainly seen in patients over the age of 65, particularly women; they are also associated with diabetes mellitus, peripheral vascular disease, collagenosis, amyloidosis, clotting and fibrinolytic disorders, overexpression of TGF-beta or erythropoetin [18].

\section{Fistula maturation}

It should be remembered that creation of an AVF for hemodialysis is no guarantee of success. The successful use of a newly created AV fistula depends on its maturation, which, in the case of a primary AVF, takes about 3 to 6 weeks (or, according to some authors, even 8 weeks). Maturation time is comparable in different age groups, e.g. children, adolescents or adults [6]; however, in people with high risk of vascular complications, maturation may take 12 to 16 weeks. An AVG can be used faster than an AV fistula - usually within 3 to 4 weeks (according to other authors 3 to 5 weeks) $[9,14,27,29]$. Maturation allows strengthening of the vessel for hemodialysis access, vein arterialization and an increase in blood flow [5]. Initially, the increase of blood flow through anastomosis causes an increase in wall shear stress and secondary activation of vascular endothelial cells. In consequence, the secretion of tissue metalloproteinases responsible for extracellular matrix remodeling also increases; hence fragmentation of the internal elastic lamina and vessel dilation. As vessel diameter increases, shear stress is gradually restored to baseline levels and vascular resistance returns to physiological levels [13, 15]. Increases in artery and vein diameters correlate with larger volume of blood flowing through the fistula at about 2 to 3 weeks of fistula creation [27]. A fistula is judged to be mature if, at 6 months of its creation, it withstands 2 to 3 dialyses during 30 days with blood flow of $300-450 \mathrm{~mL} / \mathrm{min}$ throughout a 3- to 5-hour dialysis session [30]. It should be emphasized that nearly $30 \%$ of native forearm fistulas fail to mature due to some anatomic pathology, most frequently vessel stenosis [3 I]. Other risk factors for nonmaturation include age over 65 years, female gender (smaller vein diameter and relaxation response to wall distension), arterial hypertension, diabetes mellitus and other pathologies resulting in increased vessel stiffness, calcification and atherosclerosis progression [I I].
According to KDOQI (Kidney Disease Outcomes Quality Initiative) recommendations, at six weeks after creation, blood flow of an AV fistula should be at least $600 \mathrm{~mL} / \mathrm{min}$ [32]; however, BF typically reaches 1200 $-1400 \mathrm{~mL} / \mathrm{min}$ [22, 33]. If the flow exceeds $2000 \mathrm{~mL} /$ $/ \mathrm{min}$, the fistula is referred to as hyperdynamic; it tends to coexist with circulatory insufficiency [9, 32]. Efficient hemodialysis requires a blood flow rate between 150-200 mL/min [4]. Mature AVFs withstands blood flow rates between 300 and $700 \mathrm{~mL} / \mathrm{min}$ (according to other authors $350-500 \mathrm{~mL} / \mathrm{min}$ ) [9, 22]. Typically, blood flow is set at $200-400 \mathrm{~mL} / \mathrm{min}$ [ 18 ] but is reduced to $200-250 \mathrm{~mL} / \mathrm{min}$ during the first AVF puncture to minimize the risk of blood extravasation [27]. Fistula maturation also results in vein dilation allowing multiple cannulations. Veins with a diameter of $\geq 6 \mathrm{~mm}$ and appropriate wall thickness are considered suitable for needle insertion [10]. It should be emphasized that needle insertions prior to the completion of AVF maturation, and especially within 14 days of its creation, are deemed to significantly shorten fistula survival [4]. Maturation period should be used for exercises with heat application and dynamic exercises. Warm baths help dilate the anastomosed vessels, have anti-inflammatory effects and improve lymphatic drainage. Dynamic exercises strengthen vessel walls, increase blood flow and prevent edema formation. In weeks two and three of fistula creation the patient should exercise 70 and 100 minutes a day, respectively. Alternative programs recommend 50 exercise cycles of 3 minutes each yielding 150 minutes a day [5].

\section{Complications of arteriovenous fistulas for hemodialysis}

Complications of arteriovenous fistulas for hemodialysis can be divided into early and late. Early complications include a non-functional vascular access due to inadequate maturation, arterialization and vessel dilation even if the vessel itself remains patent. Another early complication is complete patency loss in the first three or six months of creation $[10,17]$ usually due to anastomotic stenosis resulting from venous thrombosis and resultant occlusion [17]. This type of stenosis most frequently develops in a transposed venous component of an AVF and, a bit less frequently, in its arterial part or venous outflow tract [13]. The latter is associated with BF decrease and promotes thrombosis. Stenosis in the venous part of the fistula results in pressure increase inside the anastomosis, which predisposes to the development of aneurysms [29]. According to statistics, early lesions occur more frequently in fistulas with postoperative BF $>350 \mathrm{~mL} / \mathrm{min}$ compared to AVF with $\mathrm{BF}$ below that value ( $55 \%$ vs. I I.3\%, respectively). 
Elderly people and diabetic patients are more prone to early complications [28]. Too early attempts of needle insertion to the fistula, in particular within 14 days of its formation, increase the risk of complications and shorten AVF survival [4]. Compared to AVG, arteriovenous fistulas more frequently become infected and impatent [24].

Late vascular access complications include exaggerated vessel dilation, true and false aneurysms and venous stenosis at anastomosis or AVF puncture sites. Also, parietal AVF calcifications and wall thickening due to endothelial proliferation - mainly at the sites of turbulent blood flow (venous dilation, sharp vessel curves). Another complication is collateral circulation, the formation of which delays or precludes fistula maturation, reduces or reverses blood flow through a fistula $[29,33]$. The incidence of steal syndrome is higher with fistulas created within the cubital fossa ( $1-4 \%)$. Its clinical manifestations include distal extremity pallor, diminished pulses (distal to the fistula), tissue necrosis, decrease in the wrist/brachial pressure index and pain (distal to anastomotic site) [24]. Early and late complications associated with an AVF also comprise hematomas, infections, abscess formation or external compression of the outflow veins [7, 9, 27].

However, complications are not only related to the anastomotic site. AVF formation results in hyperdynamic circulation. BF in exceed of $2000 \mathrm{~mL} / \mathrm{min}$ or Qa:CO ratio greater than 0.3 ( $\mathrm{Qa}$ - flow through fistula, $\mathrm{CO}$ - cardiac output) indicate a risk for left ventricular hypertrophy and diastolic dysfunction. Treatment includes attempts to salvage the access by reducing blood flow using venous banding or inflow reduction by anastomosis distalization. If these prove ineffective, the AV fistula is closed [32].

\section{Assessment of AVF function — diagnosis and treatment}

Literature data indicate that around $30 \%$ of the AVFs do not mature for needle insertion. Hence, early detection of pathology and fistula salvage intervention are of critical importance. It is well-established that anticipative management strategies bring more benefits than any other treatment following thrombus formation. The first check of a newly formed AVF is performed within a month of its creation [28, 32, 34]. Postoperative wound healing is assessed and infection or venous thrombosis ruled out. Arterial inflow is estimated - even when much pressure is applied, a well-functioning fistula keeps pulsating. A continuous thrill extending through systole and diastole indicates appropriate venous outflow [27].
The following are used for AVF assessment: duplex Doppler ultrasonography, computed tomography angiography (CTA), magnetic resonance angiography (MRA) and invasive examinations including fistulography or digital subtractive angiography (DSA) [7, 9].

Early AVF assessment is performed using duplex Doppler ultrasonography - a valuable diagnostic and follow-up modality. Wang et al. recommend follow-up examinations on day I, week I and I 2 weeks of vascular access surgery [28]. Duplex Doppler ultrasonography is a method of choice to assess anastomosed vessel morphology. It allows accurate identification of fistula stenosis and helps estimate blood flow through the AVF. Therefore it can be predictive of efficient dialysis and, indirectly, a risk for thrombus formation. Unfortunately, the results of duplex Doppler ultrasonography largely depend on the individual examiner's skills and experience [7, 28, 33, 35].

CTA yields a spatial image of an AVF thus facilitating the selection and scope of a reparative intervention. It is a minimally invasive, repeatable and short examination. Radiation exposure and volumes of a contrast agent are lower compared to DSA. Also, computed tomography angiography is more cost-effective than DSA and MRA [7].

Fistulography is a standard method to detect venous stenoses and accessory veins. It should be performed in patients with inadequate fistula maturation, and, if needed, combined with vascular interventions including angioplasty, embolization, accessory vessel ligation, or surgical revision [27].

DSA is considered the gold standard in vessel assessment although it does not allow vessel quantification. As it is invasive and requires administration of larger volumes of contrast media, DSA has a higher rate of associated complications [7].

AVF complications can be treated using a surgical or endovascular approach. Surgical management is preferred for stenosis/thrombus of an AVF created distally on the forearm. The rate of restenosis is lower compared to endovascular interventions. Isolated short-segment venous stenoses $(<\mathrm{I} \mathrm{cm})$ are resected and an end-to-end anastomosis is performed. An alternative is stenotic segment angioplasty with a small autologous patch or artificial graft. Autologous vein or artificial grafts, e.g. PTFE, result in similar efficacy and restenosis rates. In the case of stenoses $>1 \mathrm{~cm}$ or multiple stenoses, it is recommended to create a new, more proximal AVF [34]. Surgical management is also used for nonmaturing fistulas resulting from insufficient arterial supply [27].

Balloon angioplasty is performed in patients with central venous or fistula stenosis. Access is obtained 
distally or proximally via the brachial or radial artery. A retrograde venous access device can make an acceptable alternative. Pharmacotherapy is also considered; using drug-coated balloons antiproliferative agents such as sirolimus (rapamycin) are administered directly to stenotic segments of the fistula or central veins [29]. Following angioplasty, a fistulogram must be obtained from fistula site down to the central veins [3I].

Some patients undergo venous superficialization, mainly obese individuals whose veins are deeply located (usually deeper than $\mathrm{I} \mathrm{cm}$ ) and unavailable for puncture. A $10-15 \mathrm{~cm}$ long venous segment of the fistula is dissected, the vessel bed sutured and the vessel transposed to a subcutaneous pocket $[4,27]$.

\section{Summary}

Since kidney dialysis life expectancy increases, problems and complications encountered with arteriovenous fistulas and grafts for dialysis are also more frequent. Repeated anastomosis are created more and more often. That is why AVF creation and treatment of associated complications should be tailored to the needs of an individual patient. The number of people receiving renal replacement therapy in Poland and worldwide continues to increase. It should therefore be recognized that care for maintaining good vessel condition in the pre-dialysis period, creation of a well-functioning and mature arteriovenous fistula, its proper use, early diagnosis and treatment of fistula pathologies is the basic factor to limit dialysis-related complications. Hence, life quality and survival time of patients with end-stage renal disease could be improved.

\section{References}

I. Chudek J, Wikarek T, Więcek A. Epidemia przewlekłej choroby nerek $w$ populacji osób $w$ podeszłym wieku jako nakładanie się procesu fizjologicznego starzenia i nabytych uszkodzeń nerek. Forum Nefrologiczne. 2013; 6(I): I.

2. Rutkowski B. Przewlekła choroba nerek — dziesięć lat $w$ teorii i praktyce. Forum nefrologiczne. 2013; 6(I): 63-70.

3. Magalhães LP, Dos Reis LM, Graciolli FG, et al. Predictive factors of one-year mortality in a cohort of patients undergoing urgent-start hemodialysis. PLoS One. 2017; I2(I): e0167895, doi: 10.1371/journal.pone.0167895, indexed in Pubmed: 28045952.

4. Weyde W, Krajewska M, Klinger M. Dostęp naczyniowy do hemodializy. Forum Nefrologiczne. 2008; I (3): I 19-126.

5. Zbróg M, Paradowski A, Misiewicz P. Ćwiczenia zespolenia tętniczo-żylnego do hemodializ. Forum Nefrologiczne. 2010; 3(I): 25.

6. Kim SM, Min SK, Ahn S, et al. Outcomes of arteriovenous fistula for hemodialysis in pediatric and adolescent patients. Vasc Specialist Int. 2016; 32(3): I I3-I I8, doi: 10.5758/vsi.2016.32.3. I I3, indexed in Pubmed: 27699158.
7. Zagrodzka M, Wańkowicz Z. Wartość spiralnej tomografii komputerowej $\mathrm{i}$ angiografii subtrakcyjnej $\mathrm{w}$ ocenie morfologii przetoki tętniczo-żylnej do hemodializ — doświadczenia własne. Pol Merk Lek. 2004; 17(98): I28-136.

8. Morsy M, Betal D, Nelson S, et al. Pre-emptive angioaccess for haemodialysis in the elderly. Nephrol Dial Transplant. 20I I; 26(II): 3666-3670, doi: 10.1093/ndt/gfr 104, indexed in Pubmed: 21421596 .

9. Dziekiewicz M, Wierzbicki P, Prokopiuk-Wierzbicka M. Dostęp naczyniowy do hemodializ — doświadczenia własne. Pol Merk Lek. 2008; 24(142): 316-320.

10. Huber TS, Ozaki CK, Flynn TC, et al. Prospective validation of an algorithm to maximize native arteriovenous fistulae for chronic hemodialysis access. J Vasc Surg. 2002; 36(3): 452-459, indexed in Pubmed: 12218966.

II. Marques MG, Ponce P. Pre-operative Assessment for Arteriovenous Fistula Placement for Dialysis. Semin Dial. 2017; 30(I): 58-62, doi: 10.1 I I I/sdi. 1256I, indexed in Pubmed: 27866375.

12. Krajewska M, Weyde W, Kosmala W. Wpływ przetoki tętniczo-żylnej na układ krążenia u chorych ze szczególnym zagrożeniem sercowo-naczyniowym. Pol Merk Lek. 2006; 2I(I22): | 145-I47.

13. Konner K, Lomonte C, Basile C. Placing a primary arteriovenous fistula that works-more or less known aspects, new ideas. Nephrol Dial Transplant. 2013; 28(4): 78I-784, doi: 10.1093/ /ndt/gfs463, indexed in Pubmed: 23। 25423.

14. Gupta A, Khaira A, Bhatt AP, et al. Release technique: maturing arteriovenous fistula early. Saudi J Kidney Dis Transpl. 2010; $2 \mathrm{I}$ (4): 746-747, indexed in Pubmed: 20587887.

15. van der Linden J, Lameris TW, van den Meiracker AH, et al. Forearm venous distensibility predicts successful arteriovenous fistula. Am J Kidney Dis. 2006; 47(6): 1013-1019, doi: 10.1053/j. ajkd.2006.01.033, indexed in Pubmed: 16731296.

16. Fila B, Lovčić V, Sonicki Z, et al. Vein diameter after intraoperative dilatation with vessel probes as a predictor of success of hemodialysis arteriovenous fistulas. Med Sci Monit. 2014; 20: 191-198, doi: 10.12659/MSM.890155, indexed in Pubmed: 24496387.

17. Ene-lordache B, Cattaneo L, Dubini G, et al. Effect of anastomosis angle on the localization of disturbed flow in 'side-to-end' fistulae for haemodialysis access. Nephrol Dial Transplant. 2013; 28(4): 997-1005, doi: 10.1093/ndt/gfs298, indexed in Pubmed: 22785110.

18. Brzychczy A, Lejman W, Walatek B. Wpływ niektórych czynników jakościowych i ilościowych na funkcjonowanie przetoki tętniczo-żylnej przez okres dłuższy niż 24 miesiące. Nefrol Dial Pol. 2006; 10: 12-16.

19. Letachowicz K, Weyde W, Letachowicz W. Chorzy powyżej 75 roku życia w programie przewlekłych hemodializ - ocena jakości dostępu naczyniowego i adekwatności dializy. Nefrol Dial Pol. 2009; I3: 203-205.

20. Jakes $A D$, Jani $P, A l l g a r ~ V$, et al. Arterio-venous fistula: is it critical for prolonged survival in the over 80's starting haemodialysis? PLoS One. 2016; II(9): e0163487, doi: 10.1371/journal. pone.0163487, indexed in Pubmed: 2768407I.

21. Dixon BS, Novak L, Fangman J. Hemodialysis vascular access survival: upper-arm native arteriovenous fistula. Am J Kidney Dis. 2002; 39(I): 92-101, doi: 10.1053/ajkd.2002.29886, indexed in Pubmed: I 1774107. 
22. Kharboutly Z, Deplano V, Bertrand E, et al. Numerical and experimental study of blood flow through a patient-specific arteriovenous fistula used for hemodialysis. Med Eng Phys. 2010; 32(2): III-1 I8, doi: 10.1016/j.medengphy.2009.10.013, indexed in Pubmed: 19962337.

23. Han S, Song D, Yun S. Long term outcomes of arteriovenous grafts for hemodialysis in lower extremities. Vasc Specialist Int. 2016; 32(4): 180-185, doi: 10.5758/vsi.2016.32.4.180, indexed in Pubmed: 28042558.

24. Ravari $\mathrm{H}$, Kazemzade GH, Modaghegh $\mathrm{MH}$, et al. Patency rate and complications of polytetrafluoroethylene grafts compared with polyurethane grafts for hemodialysis access. Ups J Med Sci. 2010; I I5(4): 245-248, doi: 10.3 109/0300973 I003678562, indexed in Pubmed: 20218943.

25. Suemitsu K, lida O, Shiraki T, et al. Predicting loss of patency after forearm loop arteriovenous graft. J Vasc Surg. 2016; 64(2): 395-40I, doi: 10. I016/j.jvs.2016.02.049, indexed in Pubmed: 27106244.

26. Perl J, Wald R, McFarlane P, et al. Hemodialysis vascular access modifies the association between dialysis modality and survival. J Am Soc Nephrol. 20II; 22(6): III3-1I21, doi: 10.168I/ /ASN.20101IIII55, indexed in Pubmed: 21511830.

27. Kian K, Vassalotti JA. The new arteriovenous fistula: the need for earlier evaluation and intervention. Semin Dial. 2005; 18(I): 3-7, doi: 10.1 | | |/j.1525-139X.2005.|8||4.x, indexed in Pubmed: 15663753.

28. Kim YO, Yang CW, Yoon SA, et al. Access blood flow as a predictor of early failures of native arteriovenous fistulas in hemodia- lysis patients. Am J Nephrol. 200 I; 2 I (3): 22I-225, doi: 4625I, indexed in Pubmed: I I 423692.

29. Shenoy S. Future Trends in Vascular Access Creation. Contrib Nephrol. 2017; 189: 252-256, doi: 10.1159/000450817, indexed in Pubmed: 2795। 576.

30. Kosa SD, Al-Jaishi AA, Moist L, et al. Preoperative vascular access evaluation for haemodialysis patients. Cochrane Database Syst Rev. 2015(9): CD007013, doi: 10.1002//465।858. CD007013.pub2, indexed in Pubmed: 264I8347.

31. Hsieh MY, Lin L, Tsai KC, et al. Radial artery approach to salvage nonmaturing radiocephalic arteriovenous fistulas. Cardiovasc Intervent Radiol. 2013; 36(4): 957-963, doi: 10.1007/s00270012-0533-7, indexed in Pubmed: 23238850.

32. Głowiński J, Głowińska I, Małyszko J. Kardiotoksyczność przetoki tętniczo-żylnej do hemodializ. Nefrol Dial Pol. 2012; 16: |43-|45.

33. Pietura R, Szymańska A, Janicki K. Ocena ultrasonograficzna zwężeń w prawidłowo działających przetokach dializacyjnych. Nefrol Dial Pol. 2002; 6: 230-233.

34. Lipari G, Tessitore N, Poli A, et al. Outcomes of surgical revision of stenosed and thrombosed forearm arteriovenous fistulae for haemodialysis. Nephrol Dial Transplant. 2007; 22(9): 2605-26I2, doi: 10.1093/ndt/gfm239, indexed in Pubmed: 17517799.

35. Mudoni A, Caccetta F, Caroppo M, et al. Echo color Doppler ultrasound: a valuable diagnostic tool in the assessment of arteriovenous fistula in hemodialysis patients. J Vasc Access. 2016; 17(5): 446-452, doi: 10.5301/jva.5000588, indexed in Pubmed: 27470250 . 